\title{
O alcance do acesso à justiça eficiente por intermédio do ativismo judicial
}

\author{
Reaching of the access to efficient justice through \\ judicial activism
}

\author{
Adriana Silva Maillart \\ Bruno Carlos dos Rios ${ }^{* *}$
}

\section{Resumo}

O presente trabalho possui o escopo de examinar a concepção de acesso à justiça frente ao mero ingresso formal do cidadão no processo judicial. Avaliando a concreta entrega da prestação jurisdicional por meio do fenômeno do ativismo judicial, destinada a alcançar a cabal pacificação social, a contenda gira em torno das dificuldades de ordem prática em se estabelecerem objetivamente os limites e critérios das decisões ativistas do Poder Judiciário, averiguando a função judicial na consolidação dos valores contidos na Constituição Federal. Além disso, o artigo aborda conceituações acerca do acesso à justiça eficiente e do ativismo judicial, traçando um paralelo entre os dois sistemas, haja vista a organização constitucional contemporânea referente à participação e fiscalização entre os três Poderes do Estado. Por fim, o estudo almeja examinar a adjacência da ordem jurídica justa diante das funções estatais, para que ocorra de maneira harmônica e equilibrada, sem que seja abalado um dos pilares do Estado Democrático de Direito: o princípio da separação dos Poderes.

Palavras-chave: Acesso à Justiça. Ativismo judicial. Eficiência. Separação dos Poderes.

Doutorado em Direito pela Universidade Federal de Santa Catarina. Atualmente, é coordenadora do Curso de Direito, professora do corpo permanente e pesquisadora do programa de Mestrado em Direito da Universidade Nove de Julho - Uninove. São Paulo - SP - Brasil. Email: adrissilva@ gmail.com

** Mestrando em Justiça, empresa e sustentabilidade pela Universidade Nove de Julho. Defensor Público Federal titular de Ofício Previdenciário em São Paulo. São Paulo - SP - Brasil. 


\section{Abstract}

This study has the scope to examine the concept of access to justice as regards the mere formal entry of citizens in the judicial process. Factual delivery of judicial services, through the judicial activism phenomenon, devoted to achievement of full social pacification, is evaluated. Content discusses practical difficulties in objectively establishing the limits and criteria of activist decisions of the Judiciary, ascertaining the judicial function in the consolidation of the values contained in the Federal Constitution. Conceptualizations about access to efficient justice and judicial activism, drawing a parallel between the two systems, given the contemporary constitutional arrangement regarding participation and supervision among the three State Powers, are addressed. Finally, the study aims to examine the adjacency of fair legal system, facing the state functions, in order to allow, in a harmonious and balanced way, without affecting one of the pillars of the Democratic State of Law, the occurrence of: the principle of separation of powers.

Keywords: Access to justice. Judicial activism. Efficiency. Separation of powers.

\section{Introdução}

O presente estudo objetiva sopesar o sistema do acesso à justiça e do ativismo judicial enquanto dotados do objetivo de resolver litígios na busca da pacificação social, além de possibilitar aos indivíduos reivindicarem e concretizarem os seus direitos. Trata-se, pois, de direitos humanos destinados, sobretudo, ao arrefecimento da miséria, por meio da promoção da igualdade econômica, jurídica e social.

O ativismo judicial refere-se a uma realidade notadamente presente no Estado brasileiro, sob o fundamento da manutenção do equilíbrio na tripartição dos Poderes. Com efeito, o desenvolvimento do direito de acesso à justiça deve caminhar encadeado com a evolução histórica e cultural dos povos, de modo a estabelecer qual a função do Poder Judicial na consolidação histórica dos direitos fundamentais dos cidadãos. 
O Direito ininterruptamente necessita evoluir para que possa amoldar-se à realidade social contemporânea, pois o acenado progresso sucede com o advento das chamadas gerações ou dimensões de direitos. Assim sendo, a temática em evidência será desenvolvida para inferir se o ativismo judicial denota um fenômeno voltado ao acesso à justiça qualitativa com destinação à inclusão popular e à solidariedade social, ou se simplesmente ventila atos judiciais excessivos a serem debelados pelos outros Poderes do Estado.

Com efeito, o ordenamento jurídico pátrio assegura às pessoas o mais amplo acesso à Justiça, já que petrificou como direito fundamental a assistência jurídica integral e gratuita, bem como a inafastabilidade da jurisdição (art. $5^{\circ}$, incisos XXXV e LXXIV, da Constituição Federal). Nesse contexto, a presente abordagem vem ao encontro dos anseios contemporâneos de promoção a uma justiça competente, uma vez que não mais se perfaz por meio do singelo cumprimento do acesso ao Judiciário, sendo necessário e basilar o alcance da ordem jurídica justa para todos, sem distinção de qualquer ordem, ultrapassando os meros aspectos formais do direito de ação.

O acesso à justiça eficiente consiste num dos direitos fundamentais garantidos pela Constituição e incide na maneira de o ser humano realizar-se por meio do bem-estar social, de forma a usufruir de uma boa qualidade de vida com estado de satisfação. Nesse sentido, a investigação desse tema se deve à apreciação do ativismo judicial, sob o enfoque de que o espectro contemporâneo do acesso à justiça necessita do alargamento dos objetivos e métodos da moderna ciência jurídica.

A pacificação social revela a obrigação do Estado, motivo pelo qual é salutar aferir se a elevação à justiça, como direito humano, está sendo reverenciada pelas ações governamentais, verificando quais os meios à disposição do Direito para o cumprimento e aperfeiçoamento desse preceito constitucional. Destarte, é salutar destacar que o ativismo judicial advém da ineficiência dos outros Poderes da República no estabelecimento da paz social, abrindo espaço ao Poder Judiciário 
para desempenhar uma função atípica ao dispor os ideais coletivos de justiça para os cidadãos.

É curial salientar que o ativismo judicial autentica ao Poder Judiciário operar além dos limites típicos da sua competência, devendo observância, entretanto, aos princípios institucionais estabelecidos na Constituição Federal. De tal modo, é necessário avaliar se as decisões judiciais ativistas não maculam a natureza do Judiciário e ferem as atribuições destinadas ao Legislativo e ao Executivo.

Sendo assim, o trabalho contém o intento de desenvolver a perspectiva hodierna do acesso à justiça eficiente, notadamente por meio do instrumento ativismo judicial. Por intermédio dos aludidos institutos, procurar-se-á proporcionar soluções das circunstâncias em que haja intranquilidade ao regime democrático e aos direitos humanos, constatando os acréscimos categóricos da ordem jurídica que identificam o acossamento do apaziguamento popular.

\section{O Direto humano de acesso à justiça: conceito, paradigma e eficiência}

De partida, insta salientar a passagem dos direitos humanos do estado de natureza para a sociedade civil. No estado da natureza, conviviam os homens com a liberdade de utilizar como quisessem suas capacidades para preservação da própria essência, sem quaisquer limites. Sendo assim, as três principais causas da discórdia sintetizavamse em competição, desconfiança e glória (HOBBES, 1979).

O Estado primitivo era permeado de inocência e felicidade, dentro do qual os seres humanos expunham o direito de fazer o que bem entendessem. Com efeito, aquele tempo despontava-se anárquico, violento e de discórdia entre os homens.

Deveras, a violência da conjuntura de natureza só termina por meio da criação do Estado e de seu soberano, ocasião em que os homens renunciam parte dos seus direitos em favor destes últimos, que 
os desempenham representando os governados. A vida em sociedade é tida como valor intrínseco do ser humano, designada a impetrar justiça por meio da política:

Assim, o homem é um animal cívico, mais social do que as abelhas e os outros animais que vivem juntos. [...] $O$ Estado, ou a sociedade política, é até mesmo o primeiro objetivo a que se propôs a natureza. $O$ todo existe necessariamente antes da parte. As sociedades domésticas e os indivíduos não são senão parte integrante da Cidade, todos subordinados ao corpo inteiro, todas distintas por seus poderes e funções, e todas inúteis quando desarticuladas, semelhantes às mãos e aos pés que, uma vez separadas do corpo, só conservam o nome e a aparência, sem a realidade, como uma mão de pedra. O mesmo ocorre com os membros de uma Cidade: nenhum pode bastar-se por si mesmo. Aquele que não precisa de outros homens, ou de que não pode resolver-se a ficar com eles, ou é um deus, ou um bruto. Assim, a inclinação natural leva os homens a este gênero de sociedade (ARISTÓTELES, 1999, p. 45).

Thomas Hobbes (1993, p. 104) ensina que o Estado detém o papel de evitar uma liberdade absoluta, como aquela que cada indivíduo detinha no estado da natureza. Ao condescender no pacto social, os homens dominam suas vontades a uma veemência maior absoluta, aceitando uma sociedade na qual "cada indivíduo da cidade transferiu todo este direito de guerra e de paz para um homem ou um conselho".

Diante disso, abrolha o contratualismo, que, por sua vez, consiste na transferência mútua de direitos. Por meio dele, os homens caracterizam-se como iguais e detentores das mesmas faculdades jurídicas, visto que a sociedade política deriva de um contrato específico e limitado, dotado do poder de solucionar litígios e proteger os direitos de propriedade (LOCKE, 1983).

Os direitos humanos não descobrem sua legitimação em determinado documento normativo peculiar ou ordenamento supralegal de cunho jusnaturalista, e sim em um brando progresso histórico. Isso porque os direitos nascem e se transformam em contrapartida a um 
sentimento da sociedade, que passa a ser estabelecido pelos Estados, em imprescindível alicerce no conceito de dignidade da pessoa humana:

Os Direitos Humanos nascem, se desenvolvem e se modificam - mas não morrem - nas gerações ou dimensões seguintes, obedecendo a um núcleo existencial traduzido e sedimentado num período inserido no contexto social, a partir da ideia de dignidade da pessoa humana. (SILVEIRA; ROSACOLANO, 2010, p. 200)

Com efeito, a geração internacional dos direitos humanos decorre de um acontecimento recente na história mundial, tendo sido materializados a partir da Segunda Guerra Mundial. A intensificação desses direitos ocorreu após o nazismo, quando foram notadas as atrocidades praticadas contra o ser humano, perpetradas por técnicas de extermínios em massa através de câmaras de gás e fornos crematórios, além de trabalhos cruéis e degradantes.

Desse modo, a Declaração Universal de Direitos Humanos (1948) resulta na inicial peregrinação para que os Estados soberanos acolhessem preceitos internos e internacionais de proteção aos direitos humanos (ANNONI, 2003). Por conseguinte, o Estado brasileiro possui o dever de defendê-los, tanto pela norma cogente estabelecida na Constituição Federal quanto por ser signatário de tratados internacionais, como a aludida Declaração Universal de Direitos Humanos e a Convenção Americana de Direitos Humanos (1969).

Härbele (2007) explica que o Estado localiza sua identidade no Direito Internacional mediante a solidariedade proveniente da cooperação e responsabilidade internacionais, ocasionadas pela aproximação das relações internacionais e supranacionais. Portanto, a rigor, o entendimento da sociedade em seu sentido plural se dá por meio da abertura ao debate de forma constante, uma vez que as coletividades são permeadas pelas diferenças jurídicas, econômicas, sociais, científicas e culturais.

A fase moderna dos direitos humanos possui como marco a proteção internacional aos direitos universais, inalienáveis, destinados 
a todos os humanos, principalmente às minorias, independentemente de sua origem, etnia, raça, convicção econômica, política, social, idade, identidade sexual ou orientação religiosa. Por isso, os direitos fundamentais da pessoa humana referem-se àqueles que toda pessoa detém e cuja privação cause uma grande ofensa à justiça.

Nesse contexto, a criação, desenvolvimento e formação dos direitos humanos levam em conta a realidade fática, os valores éticos e morais da sociedade. A força dos acontecimentos sociais permeia a devotada modificação daquilo que a comunidade julga necessário para a plenitude da dignidade humana, outorgando inferir que o nascimento e o desenvolvimento dos direitos humanos decorrem de um processo dinâmico, ou seja, uma dinamogenesis que ressalta o conhecimento dos valores pela sociedade, respectiva adesão social e, por fim, a solidificação desses valores pelo direito (SILVEIRA; ROCASOLANO, 2010).

Os direitos humanos são tidos como essenciais à existência do homem na sociedade, sendo perfilhados como direitos mínimos dedicados a todas as pessoas dos quais o Estado deve respeitar no valor da dignidade humana. Nesse sentido:

A dignidade da pessoa humana [...] está erigida como princípio matriz da Constituição, imprimindo-lhe unidade de sentido, condicionando a interpretação das suas normas e revelando-se, ao lado dos Direitos e Garantias Fundamentais, como cânone constitucional que incorpora as exigências de justiça e dos valores éticos, conferindo suporte axiológico a todo o sistema jurídico brasileiro. (PIOVESAN, 2000, p. 54)

A dignidade da pessoa humana é estabelecida como um dos princípios vetores da vida em sociedade, sendo umbilicalmente ligada à concepção da gradação da justiça eficiente. Posto isso, é salutar registrar que os direitos nasceram em diferentes períodos de tempo e, por conseguinte, desenvolveram as acenadas gerações de direitos humanos que não se excluem entre si, pois vivem em perfeita consonância. 
Sendo assim, o desígnio dos Direitos Humanos traduz-se na deferência ao ser humano, especialmente no que toca à diversidade cultural. Por isso, os direitos humanos são divididos em três dimensões que convivem harmonicamente entre si: os direitos de primeira geração ou liberdades públicas negativas (civis e políticos); os direitos de segunda geração (econômicos, sociais e culturais); e, por fim, os direitos de terceira geração (direitos metaindividuais de titularidade da coletividade).

Dentro dessa classificação, o direito de acesso à justiça aventa um direito humano civil e político capitulado, portanto, dentro da primeira geração de direitos humanos. Com efeito, essa ferramenta é utilizada, inclusive, para alcançar a defesa dos outros direitos humanos básicos interligados com o princípio da dignidade humana.

O direito de acesso à justiça é inerente ao indivíduo, pois consiste na base para que os cidadãos possam ter conhecimento dos demais direitos existentes. Nesse sentido, dentro da legislação pátria o acesso à justiça encontra-se inscrito no artigo $5^{\circ}$ da Constituição Federal. Não obstante isso, é essencial repisar que os direitos fundamentais significam direitos históricos conquistados por lutas gradativas, senão vejamos:

Os direitos do homem, por mais fundamentais que sejam, são direitos históricos, ou seja, nascidos em certas circunstâncias, caracterizados por lutas em defesa de novas liberdades contra velhos poderes, e nascidos de modo gradual, não todos de uma vez, nem de uma vez por todas (BOBBIO, 1992, p. 5).

O acesso à justiça possui a relevância de viabilizar a proteção e a garantia de outros direitos igualmente humanos. Sendo assim, faz-se necessário que o Estado fortaleça os modos e os meios imprescindíveis para a aproximação da justiça qualitativa, pois estudos revelaram a complexa existência da discriminação social no acesso à justiça que "envolve condicionantes sociais e culturais resultantes de processo de socialização e de interiorização de valores dominantes muito difíceis de transformar" (SANTOS, 1995, p. 171). 
Por conta disso tudo, o acesso à justiça não se restringe na tradicional conceituação de utilização dos instrumentos processuais em juízo, mas alude o entendimento de um sistema jurídico democrático que objetiva o desenvolvimento do cidadão. Destarte, torna-se necessária a pulverização de conhecimentos acerca do Direito e das formas de amparo jurídico, de maneira a impedir opressão pelos detentores do poder estatal ou do poder econômico:

Nossa interpretação do que é possível em nossa situação e posição pode ser crucial para a intensidade de nossos desejos, e pode afetar até mesmo o que ousamos desejar. Os desejos refletem compromissos com a realidade, e a realidade é mais dura com uns do que com outros. $O$ destituído desesperançado que deseja somente sobreviver, o trabalhador sem-terra que concentra seus esforços em garantir a próxima refeição, a empregada doméstica em regime de dia-e-noite que anseia umas poucas horas de descanso, a dona de casa subjugada que luta por um pouco de individualidade podem ter, todos eles, aprendido a ajustar seus desejos a suas respectivas condições. As destituições que sofrem são silenciadas e abafadas pela métrica interpessoal da satisfação de desejos. Em algumas vidas, as pequenas mercês têm de contar muito (SEN, 1985, p. 191).

Deve-se buscar uma resolução prática para as diversas questões referentes aos problemas do acesso à justiça, uma vez que apreende o desígnio de garantir e proclamar direitos. Com efeito, malgrado o acesso à justiça seja um direito fundamental da sociedade contemporânea, o conceito de eficiência ainda não é bem definido e explorado pelos juristas.

De tal modo, a conceituação de acesso à justiça para uma ordem jurídica justa dentro do Poder Judiciário pode ser alcançada na presença de quatro requisitos: possibilidade de proposituras de ações judiciais; possibilidade do cidadão em manter a demanda até a efetiva entrega da prestação judicial; possibilidade do jurisdicionado receber resposta de mérito em prazo razoável; e, por fim, possibilidade da decisão judicial 
fornecer concretude aos direitos existentes, permitindo com que o Poder Judiciário suprima as lacunas afirmativas deixadas pelos Poderes Legislativo e Executivo.

O abarcamento da justiça qualitativa consiste em uma das maneiras de concretizar os direitos humanos, porquanto deve ser garantida a todos. Dessa sorte, carece-se obter o avesso do acesso à justiça, ou seja, o cidadão que consegue adentrar no Judiciário deve conquistar uma resposta jurisdicional que afiance eficácia no mundo dos fatos, devendo ser prolatada com exame acurado, reflexão e discussão necessária à consecução da mais lídima justiça.

Posto isso, o hodierno desafio consiste no contorno da efetivação da justiça por meio do aperfeiçoamento dos teores das decisões judiciais, a serem dotadas de concretude prática dentro de um espaço de tempo razoável. Nesse contexto, a justiça hábil demanda uma tutela jurisdicional justa, adequada, efetiva e tempestiva, largando em alto grau bem adiante da mera formalidade de submergir o cidadão no átrio do Poder Judiciário.

\section{Ativismo judicial: direito comparado, virtudes e intenções}

O ativismo judicial consiste, em linhas gerais, numa atitude proativa do Poder Judiciário ao adentrar nas opções políticas dos outros poderes do Estado. Destarte, significa um distúrbio no exercício da função jurisdicional, em prejuízo das funções legislativa, administrativa e de governo (RAMOS, 2010).

Por conta disso, é relevante ponderar o Direito Comparado tendo em vista a sua importância entre os diferentes sistemas de justiça do ocidente. Isso porque o ativismo judicial se alude de acordo com a ponderação do exercício da função jurisdicional.

No Civil Law (sistema romano-germânico), a jurisprudência se movimenta dentro dos patamares estabelecidos pelo legislador, ao passo que a atividade legislativa objetiva formar os respectivos 
parâmetros. Trata-se do sistema jurídico mais disseminado no mundo em que é sistematizado pelo fenômeno da codificação e que as leis são as principais fontes adotadas pelo Direito.

Já o Commow Law (sistema anglo-saxão), baseia-se mais na jurisprudência (principal fonte) do que no texto da lei. Nesses casos, a decisão judicial desempenha dupla função: resolve a controvérsia (res judicata) e tem valor de precedente, obrigando o tribunal e os juízes subordinados.

É salutar ressaltar que a atual dependência e energização da criatividade da função judiciária aplicam-se a ambas as famílias jurídicas, traçando uma aproximação entre os dois sistemas jurídicos do Direito ocidental. No entanto, existem diversificações na criação judiciária do direito entre as duas famílias.

No Common Law, a legislação é integrada no Direito somente quando a sua abrangência for determinada por decisões judiciais, pois o Direito legislativo é tido como fonte excepcional do Direito. Entretanto, não há confusão entre as funções do juiz e do legislador, uma vez que o juiz, ao adverso do legislador, encontra-se obrigado a motivar suas decisões (argumentação técnico-jurídica).

O ativismo judicial não se atrela a um sistema jurídico específico, embora se revele mais próximo aos sistemas constitucionais da família romano-germânica (princípio da separação dos Poderes). Isso porque no Common Law existe uma proximidade bem maior entre a atuação do juiz e do legislador no que tange à produção de normas jurídicas.

O ativismo aperfeiçoa o Direito perante as novas reivindicações sociais e pautas axiológicas, em contraposição ao passivismo. 0 aleatório excesso nas atribuições do legislativo desloca-se para a discussão da filosofia política, em que o questionamento fundamental não é a consistência jurídica da atuação ousada do Judiciário, e sim sua legitimidade (RAMOS, 2010).

A juridicização do poder permite o surgimento do Estado Democrático, garantindo a presença das diversas forças sociais na 
distribuição do poder. Com efeito, o princípio da separação dos Poderes consiste em um dos aspectos submetidos ao constitucionalismo, em que as funções do Estado são atribuídas a estruturas orgânicas independentes entre si, isto é, três funções a três diferentes órgãos: Executivo, Legislativo e Judiciário (MONTEQUIEU, 1999).

Assinala-se, de regra, o estilo executório das decisões judiciais como meros atos de aplicação das normas, ao contrário da natureza criativa ou inovadora da legislação. Apesar disso, as decisões judiciais também possuem feições criativas e inovadoras porquanto não se restringem a reportar o que se encontra nos escritos, visto que são amoldadas diante da conjuntura fática que demandou a jurisdição. Entretanto, não se nega que a liberdade de criação deferida pelo sistema jurídico ao magistrado é significativamente menor do que aquela reservada ao Poder Legislativo (KELSEN, 2003).

O ativismo judicial provém dos Estados cujas Constituições adotam como dogma a independência e harmonia entre os Poderes, embora não esteja com eles associados. O magistrado age no caso concreto para solucionar a controvérsia, enquanto que o legislador edita regras gerais, abstratas e inovadoras.

As decisões judiciais formam a manifestação do poder discricionário inseparável à atividade interpretativa, uma vez que, entre a discricionariedade legislativa e judicial, existe apenas uma diferença de grau, isto é, quantitativa e não qualitativa. A vinculação do legislador a um aspecto material é muito mais reduzida do que a vinculação do juiz, haja vista que o legislador está sujeito apenas às normas constitucionais.

O juiz encontra-se sujeito a condicionamentos jurídicos mais intensos, pois, ao contrário do legislador e administrador, não se guia por critérios de conveniência e oportunidade política, mas sim por sua própria perspectiva de qual seria a solução justa para o caso. Haverá liberdade mínima do juiz se o texto normativo for preciso e objetivo, mas liberdade máxima se a solução da controvérsia demandar a integração de lacuna, apontando-se que entre esses dois extremos situam-se a maior parte dos casos submetidos a julgamento (RAMOS, 2000). 
O emprego pelo legislador de conceitos vagos não implica em falha na técnica legislativa, de contrário significa uma determinada técnica de regulação que permite ao intérprete-aplicador maior espaço para obter as finalidades pretendidas. O magistrado não se guia por critérios de conveniência e oportunidade política e sim por sua própria perspectiva de qual seria a solução justa para o caso. A repetição do julgamento de casos similares, com adoção do entendimento prevalente no leading case, servirá para dar mais objetividade àquele critério valorativo, reduzindo a discricionariedade judicial.

No campo da filosofia do direito trabalha-se formulando uma interrogação como modo de instigar o raciocínio: por qual razão debatemos arduamente, votamos, elegemos, etc., se há um grupo de juízes, não eleitos, que decidem por nós? Essa colocação assinala que os juízes, que são uma minoria, subsistem a maioria, e afetam a base da democracia. Para que isso ocorra deve haver uma justificação e um limite. A justificação está sustentada na noção de democracia constitucional, posto que a ela interessa não só a regra da maioria, senão a tutela das minorias. Nesse sentido, os juízes são guardiões da Constituição e, portanto, das instituições e dos direitos individuais. O limite é importante, porque a atuação não deve estar destinada a substituir a vontade das maiorias ou minorias, mas assegurar o procedimento para que ambas se expressem. De tal modo, a atuação dos juízes não deve ser, neste sentido, substantiva, mas procedimental, garantindo os instrumentos para uma expressão diversificada e plural, em vez de substituí-la por opiniões próprias. Devem sustentar as regras da Democracia e a República, que são essenciais para que a sociedade discuta e resolva seus problemas, e não tentar substituir esse debate, salvo situações extremas (LORENZETTI, 2009, p. 336).

Assim sendo, restringe-se a discricionariedade do juiz ao plano de compreensão do significado dos dispositivos legais. Portanto, o juiz sempre deve buscar a solução mais satisfatória à paz e à ordem social, 
ao contrário do administrador, que se volta aos objetivos materiais ordenados em consonância com os planos de governo.

A categoria teórica da discricionariedade, em qualquer uma de suas vertentes, está fortemente vinculada ao princípio da separação dos Poderes, razão pela qual se denotam importantes as construções doutrinárias que permitam indicar os limites normativos da discricionariedade judicial:

Assim, creio que nesses casos de criação judicial do direito, o que move os juízes a manipularem o sentido literal das normas jurídicas, descobrindo novos significados para esses textos legais, está intimamente relacionado com o sentimento de justiça que carregam. Não satisfeitos com os resultados que poderão advir de uma aplicação ortodoxa da lei, esses juízes procuram manejar o sentido da norma a ser interpretada de forma a que se conforme com seus padrões de justiça, ainda que o legislador tenha imaginado ou querido resultados diversos. Há, por parte do juiz, um descontentamento com a opção previamente dada pelo legislador, fazendo com que ele (o juiz) busque uma outra opção que se ajuste melhor ao que se espera de uma 'boa' decisão judicial (NOJIRI, 2009, p. 164-165).

Existe uma visão negativa do fenômeno por desnaturar a atividade típica do Poder Judiciário em detrimento dos demais Poderes. O positivismo liberal propugnava a primazia absoluta do texto normativo sobre a atividade do intérprete-aplicador, eliminando o ativismo judicial e levando ao passivismo judiciário.

O passivismo está radicado no interpretativismo: o textualismo e o originalismo. O textualismo determina que toda interpretação constitucional considere apenas o texto da Constituição. Já o originalismo toma a Constituição com o mesmo autoritarismo que o textualismo, mas vai além da mera linguagem textual, levando em consideração o significado que os constituintes ou as ratificações pretenderam dar ao texto. 
No Direito comparado, a teoria contribuiu para que os Estados Unidos pendessem para o não interpretativismo, subdividindo-se nas correntes do conceitualismo e do simbolismo. O conceitualismo reconhece que a sociedade evolui e muda, e o significado da Constituição evolui de acordo com os conceitos básicos derivados (pela Corte) do próprio documento. O simbolismo permite que a Corte lance mão das aspirações fundamentais à história e tradição norte-americanas (definidas pela Corte) para determinar a constitucionalidade das ações das diferentes ramificações políticas do governo.

O não interpretativismo conceitualista é identificado como um originalismo moderado, que aponta as insuficiências do literalismo e do originalismo estrito sob as formas argumentativas aparentemente originalistas. Por isso se justifica a presença, no texto constitucional, de cláusulas genéricas ou indeterminadas, por corresponderem à intenção deliberada do Constituinte de permitir ao Poder Judiciário a adaptação da Constituição a novas circunstâncias.

A teoria positivista da interpretação encaixa-se no modelo estadunidense, no qual se tem a preferência dos elementos metodológicos da invocação de precedentes e os de ordem gramatical e histórica (interpretação criativa de perfil positivista). Já o simbolismo se afasta do positivismo e se aproxima do moralismo jurídico, uma vez que permite ao Judiciário utilizar aspirações fundamentais da história e tradição norte-americanas, envolvendo a utilização de valores que vão além daqueles constitucionalizados pelos autores da Constituição.

Nos EUA, o ativismo serve para caracterizar qualquer modalidade de não interpretativismo, mesmo que não contrário aos postulados positivistas. Assim, a expressão "ativismo judicial" possui uma carga valorativa positiva ou negativa. Para os adeptos do literalismo e originalismo, toda prática judiciária que não se filie ao interpretativismo é ativista.

Já os defensores do não interpretativismo não veem o ativismo de forma negativa, em razão da inevitabilidade da criatividade jurisprudencial, ao passo que o passivismo deve ser combatido. $O$ 
conceitualismo não seria ativista, pois, diferentemente do simbolismo, prevê o respeito aos limites da Constituição.

O positivismo pós-kelseniano aceita a criatividade como inerente ao processo de concretização normativa, porém, por outro lado, impõe ao juiz que se atenha à natureza predominantemente executória de suas funções. O positivismo clássico nos remete ao passivismo, ao passo que o pragmatismo e o moralismo jurídico desembocam em ativismo judiciário.

No positivismo clássico, a interpretação se submete à vontade do legislador. A consequência do pragmatismo e do moralismo jurídico consiste no ativismo subjetivista do intérprete-aplicador. No positivismo moderado ou renovado, prevalece a vontade da lei, não no sentido de um pressuposto prévio, mas no sentido de que o texto normativo objeto de exegese contém algo de objetivo que não pode ser desconsiderado, embora constitua apenas um limite de trabalho de construção da norma de decisão, em que também conta a vontade do intérprete.

Dworkin (1999) é um dos mais influentes representantes do pensamento moralista, contudo, persevera em negar que sua concepção de integridade do direito vá ao encontro do ativismo judicial. Segundo Dowrkin, o ativismo é uma forma de pragmatismo jurídico, ao passo que um juiz ativista ignoraria o texto da Constituição, a história de sua promulgação, as decisões anteriores da Suprema Corte que buscaram interpretá-la e as duradouras tradições da cultura política.

O direito como integridade condena o ativismo e qualquer prática de jurisdição constitucional, insistindo para que o juiz aplique a Constituição por meio da interpretação. Para Dworkin (1999), a alternativa ao passivo não é um ativismo tosco, atrelado apenas ao senso de justiça de um juiz, porque não se deve ceder espaço à tirania, ignorarando-se tudo para se impor aos outros poderes do Estado.

Dworkin (1999) diz que o direito como integridade postula a existência, mesmo nos casos difíceis (hard cases), de apenas uma solução hermenêutica correta. Ao contrário do pragmatismo, Dworkin 
entende não estar dando ensejo ao ativismo judiciário porquanto o seu protótipo de juiz não decide livremente, mas sim vinculado à prática constitucional de um país que adote a visão do direito como integridade.

Não nos atemoriza, em mais esta oportunidade, afirmar que a verdade está no meio-termo, na conciliação dos extremos, devendo o juiz ser considerado livre, não perante a lei e os fatos, mas sim dentro da lei, em razão dos fatos e dos fins que dão origem ao processo normativo [...] a interpretação de uma norma envolve o sentido de todo o ordenamento a que pertence.

Dentro desse contexto, o Poder Judiciário brasileiro se fortaleceu e a sua participação nas deliberações de assuntos relevantes para a sociedade tornou-se frequente. A influência da justiça na história política cresceu na medida em que nada mais se esquiva do exame judicial, visto que, além de julgar litígios entre particulares e entre particulares e o Estado, o Poder Judiciário, dotado de independência constitucional, passou a decidir, de mérito, as pelejas políticas que são frequentemente colocadas ao seu crivo:

Judicialização significa que algumas questões de larga repercussão política ou social estão sendo decididas por órgãos do Poder Judiciário, e não pelas instâncias políticas tradicionais: o Congresso Nacional e o Poder Executivo em cujo âmbito se encontram o Presidente da República, seus ministérios e a administração pública em geral. Como intuitivo, a judicialização envolve uma transferência de poder para juízes e tribunais, com alterações significativas na linguagem, na argumentação e no modo de participação da sociedade. $\mathrm{O}$ fenômeno tem causas múltiplas. Algumas delas expressam uma tendência mundial; outras estão diretamente relacionadas ao modelo institucional brasileiro (BARROSO, 2008, p.6).

Pelo exposto, conclui-se que um sistema judicial proativo dedica acolher com excelência a população para capacitá-la a participar do Estado Democrático, solidificando a função imperativa de materializar os ideais da verdadeira justiça. 


\section{Justiça eficiente e ativismo judicial: fórmulas para o alcance da ordem jurídica justa}

O Estado de Direito é o componente primordial do constitucionalismo moderno, pois demanda um governo de leis, e não de homens, com o objetivo de impedir o arbítrio dos governantes. Nesse contexto, a democracia é o princípio da atribuição do poder adotada pelo constitucionalismo, ao passo que "o estabelecimento de Constituição é visto como o mesmo que a instituição da democracia e a instituição da democracia passa pela adoção da Constituição" (FERREIRA FILHO, 2009, p. 43).

A pós-modernidade demanda uma modernidade líquida em que se descobre constante processo de mutação. Por conta disso, os episódios aparecem em estado de liquidez, pela incapacidade de manter sua forma, isto é, as mudanças culturais caracterizam a adjacente e maior dinamicidade em relação à modernidade sólida (BAUMAN, 2001).

Por conseguinte, o Direito contemporâneo necessita de mecanismos que o tornem realizável. Os direitos e as garantias individuais do cidadão acondicionam conquistas normativas a uma ordem jurídica justa, por meio da promoção da justiça qualitativa:

O constitucionalismo moderno permite um exame das relações entre a decisão judicial e sistema político não apenas sob a ótica da divisão de poderes, mas também a partir de uma discussão sobre o Estado de Direito. Estado de Direito não significa exclusivamente observância dos princípios da legalidade e da publicidade dos atos administrativos, legislativos e judiciais. Significa, igualmente - e, para os efeitos aqui buscados, esse é o aspecto fundamental - controle jurisdicional da atuação do Legislativo e do Executivo. Evidentemente, esse controle só pode ser compreendido como uma projeção aplicativa dos princípios da legalidade e publicidade. Mas é exatamente nesse ponto, ou seja, no controle jurisdicional dos demais Poderes, que reside o caráter eventualmente político da decisão judicial. Aqui, também os problemas 
fáticos são enormes: transformações importantes na forma e no conteúdo da legalidade promoveram modificações profundas no conceito do Estado de Direito e, por via de consequência, nos papéis atribuídos ao Judiciário. (CAMPILONGO, 2002, p. 42).

A Constituição Federal brasileira instituiu fundamentalmente que são Poderes da União o Legislativo, o Executivo e o Judiciário, assegurando a eles a independência e harmonia entre si, cada qual com sua função deliberativa. As principais funções do Estado foram divididas para que não fosse concentrado todo o poder nas mãos de um único mortal:

Estaria tudo perdido se um mesmo homem, ou um mesmo corpo de principais ou de nobres, ou do Povo, exercesse três poderes: o de fazer as leis; o de executar as resoluções públicas; e o de julgar os crimes ou as demandas dos particulares. [...] É uma experiência eterna que todo homem que tem poder é levado a abusar dele (MONTESQUIEU, 1999, p. 165-168).

O mote principal da atividade do Poder Judiciário é a resolução do litígio no caso concreto, predominando a atuação executória e aplicativa em relação à criativa e prescritiva. Entretanto, as hipóteses de ultrapassagem dos marcos normativos materiais não significa, por si só, que uma decisão ativista esteja invadindo a esfera de outro Poder na seara projetada por um texto normativo.

Mauro Cappelletti e Bryant Garth (1988) expõem três ondas renovatórias para a resolução da problemática do acesso à justiça: assistência judiciária para os pobres; representação jurídica para os interesses difusos; e, por fim, enfoca no instituto do acesso à justiça ou maneira de ser do processo judicial, apontando formas de resolução de litígios. Nesse sentido, os aludidos doutrinadores defendem essas transformações para o alargamento do direito de acesso à justiça, por meio de novos contornos de ações coletivas e métodos alternativos de resolução de conflitos: 
Não é surpreendente, portanto, que o direito ao acesso efetivo à justiça tenha ganho particular atenção na medida em que as reformas do welfare state têm procurado armar os indivíduos de novos direitos substantivos em sua qualidade de consumidores, locatários, empregados e, mesmo, cidadãos. De fato, o direito ao acesso efetivo tem sido progressivamente reconhecido como sendo de importância capital entre os novos direitos individuais e sociais, uma vez que a titularidade de direitos é destituída de sentido, na ausência de mecanismos para sua efetiva reivindicação (CAPPELLETTI; GARTH, 1988, p. 11).

O ativismo judicial, umbilicalmente ligado à concretização das ondas renovatórias do acesso à justiça, depara-se acoplado a uma nova maneira de pronunciar o direito independente do simples positivismo jurídico. Por conta disso, no Brasil os controles judiciais de políticas públicas e atos de governo acontecem por intermédio de ações coletivas e parcerias entre os Poderes do Estado:

Aideia de ativismo judicial está associada a uma participação mais ampla e intensa do Poder Judiciário na concretização de valores e fins constitucionais, com maior interferência no espaço de atuação dos outros dois Poderes. A postura ativista se manifesta por meio de diferentes condutas, que incluem: (i) a aplicação direta da Constituição a situações não expressamente contempladas em seu texto e independentemente de manifestação do legislador ordinário; (ii) a declaração de inconstitucionalidade de atos normativos emanados do legislador, com base em critérios menos rígidos que os de patente e ostensiva violação da Constituição; (iii) a imposição de condutas ou de abstenções ao Poder Público, notadamente em matéria de políticas públicas. (BARROSO, 2008, p. 4).

Nessa conjuntura, é importante ressaltar a distinção entre o ativismo judicial e a judicialização da política: o ativismo judicial consiste na participação maior do juiz por meio da hermenêutica jurídica expansiva, com o objetivo de oferecer o direito das partes e materializar as normas constitucionais, sem que seja invadida a seara da criação 
do direito; já a judicialização da política consiste no deslocamento da decisão de certas questões que tradicionalmente eram de competência dos Poderes Executivo e Legislativo:

A judicialização e o ativismo judicial são primos. Vêm, portanto, da mesma família, freqüentam os mesmos lugares, mas não têm as mesmas origens. Não são gerados, a rigor, pelas mesmas causas imediatas. A judicialização, no contexto brasileiro, é um fato, uma circunstância que decorre do modelo constitucional que se adotou, e não um exercício deliberado de vontade política. Em todos os casos referidos acima, o Judiciário decidiu porque era o que Ihe cabia fazer, sem alternativa. Se uma norma constitucional permite que dela se deduza uma pretensão, subjetiva ou objetiva, ao juiz cabe dela conhecer, decidindo a matéria. Já o ativismo judicial é uma atitude, a escolha de um modo específico e proativo de interpretar a Constituição, expandindo o seu sentido e alcance. Normalmente ele se instala em situações de retração do Poder Legislativo, de um certo descolamento entre a classe política e a sociedade civil, impedindo que as demandas sociais sejam atendidas de maneira efetiva.

A idéia de ativismo judicial está associada a uma participação mais ampla e intensa do Judiciário na concretização dos valores e fins constitucionais, com maior interferência no espaço de atuação dos outros dois Poderes. A postura ativista se manifesta por meio de diferentes condutas, que incluem: (i) a aplicação direta da Constituição a situações não expressamente contempladas em seu texto e independentemente de manifestação do legislador ordinário; (ii) a declaração de inconstitucionalidade de atos normativos emanados do legislador, com base em critérios menos rígidos que os de patente e ostensiva violação da Constituição; (iii) a imposição de condutas ou de abstenções ao Poder Público, notadamente em matéria de políticas públicas. (BARROSO, 2008, p. 6).

O Estado brasileiro detém a obrigação de diligenciar a dignidade da pessoa humana, a redução das desigualdades sociais, a proteção do Estado Democrático de Direito, a prevalência dos direitos humanos, 
a garantia da ampla defesa e do contraditório. Igualmente, o Estado de Direito foi instituído para garantir o exercício dos direitos sociais, individuais, a liberdade, a segurança, o bem-estar, o desenvolvimento, a igualdade e a justiça para uma sociedade fraterna, pluralista e sem preconceitos.

Dessa maneira, o panorama constitucional avulta o comportamento do Estado e impõe a execução de políticas públicas de acordo com a determinação constitucional referente à manutenção e concretização dos direitos fundamentais. Assim sendo, o ativismo judicial é destinado à tranquilidade social e à diminuição das desigualdades, permitindo que seja desenvolvido com melhor alcance aquilo que a Constituição e a sociedade esperam e precisam:

Pois o Estado social contemporâneo, que repudia a filosofia política dos 'fins limitados do Estado', pretende chegar ao valor do homem através do culto à justiça e sabe que, para isso, é indispensável dar ao conceito de 'justiça' um conteúdo substancial e efetivo. É preciso reduzir as diferenças sociais e econômicas tanto quanto possível, gerando oportunidades. É preciso assegurar a fruição, por todos, dos bens materiais e imateriais que integram o patrimônio comum da nação. É preciso criar efetivas condições para a mobilidade sócioeconômica, inclusive mediante a liberdade de associação. E o Estado, então, pretendendo ser a 'providência de seu povo', sente que o bem-estar coletivo depende intimamente da sua participação efetiva nos destinos da população. Ele é, por isso, declaradamente intervencionista, agindo sobre a ordem econômica e social e buscando a sua modelagem segundo os objetivos da ideologia aceita. O 'pacto social' refletido na nova ordem constitucional inclui o traçado de diretrizes nesse sentido da integração social e econômica da população (DINAMARCO, 1999, p. 31).

Incumbe ao Estado destinar igualdade material à sociedade, ansiando extirpar as desigualdades existentes. $O$ ativismo judicial consiste numa ferramenta de consonância e balanceamento entre os 
Poderes da República, consolidando as contendas democráticas que almejam as melhores soluções para os conflitos proporcionados.

As decisões ativistas do Judiciário, notadamente do Supremo Tribunal Federal, precisam ser tratadas como cátedra pedagógica, uma vez que são prolatadas diante do vazio deixado pelo Legislativo e Executivo. Desta feita, tal fenômeno coopera para diminuir a sensação social de descrédito e a impressão de abandono ocasionada pela vagarosidade e falha dos outros Poderes.

Eventual impaciência em relação ao ativismo judicial, por parte dos membros dos Poderes políticos, não merece prosperar, porque o fenômeno obedece às finalidades dos comandos constitucionais. Nesse passo, os membros do Poder Judiciário são obrigados a apresentar as respostas colocadas pelos cidadãos, ao passo que essa prática ativista pode e deve ser extinta na proporção em que os demais Poderes venham a desempenhar suas funções e competências com a eficiência determinada na Constituição Federal.

A intervenção judicial em evidência deve respeitar a razoabilidade, de forma que a medida judicial adotada esteja conectada ao interesse público e apropriada à persecução de seus fins. Além disso, é necessária demonstração de que não havia outro meio menos oneroso para conseguir o fim almejado, sendo imprescindível empregar a carga coercitiva justa para a obtenção do resultado pretendido:

A aplicação do Princípio da Proporcionalidade na solução de um caso concreto se dá pela verificação, na espécie, da presença de três elementos essenciais: a adequação dos meios utilizados pelo legislador na consecução dos fins pretendidos; a necessidade da utilização daqueles meios (e de nenhum outro, menos gravoso, em seu lugar); e a efetiva razoabilidade da medida (proporcionalidade em sentido estrito), aferida por meio de uma rigorosa ponderação entre o significado da intervenção para o atingido e os objetivos perseguidos pelo legislador (BUECHELE, 1999, p. 58). 
Nessas situações, não há violação do princípio da separação dos poderes, uma vez que as ingerências recíprocas de um poder em outro possuem o desígnio de avigorar o equilíbrio e a independência dos Poderes estatais. Sendo assim, ocorre o desempenho da justiça qualitativa ao abonar prestações ativas para a abrangência da justiça social, promovendo o bem de todos em benefício do desenvolvimento social.

Destaca-se que o ativismo judicial não permite que o magistrado se demude em gestor de políticas públicas e deturpe sua competência constitucionalmente estabelecida. Ao revés, esse sistema indica uma postura ativa do Estado para com o cidadão, garantindo a concretização dos direitos individuais e coletivos por intermédio da entrega da ordem jurídica justa ao jurisdicionado.

Cabe ao Poder Judiciário intrometer-se nas políticas públicas dando cumprimento a preceitos e normas programáticas. Ademais, incumbe aos magistrados adentrar no mérito do ato administrativo, nas excepcionais hipóteses em que sejam necessários o preenchimento e a concretização das normas jurídicas positivadas.

Nas circunstâncias em que o exercício da discricionariedade administrativa pelo não desenvolvimento de definidas políticas públicas ocasione grave vulneração a direitos e garantias fundamentais afirmados pela Constituição, a intervenção do Poder Judiciário se justifica para programar, concreta e eficientemente, os valores que o constituinte selecionou como importantes para uma sociedade fraterna, pluralista e sem preconceitos.

Atendidos os princípios da proporcionalidade e razoabilidade, cabe ao Judiciário, em extraordinárias conjecturas, o controle de políticas públicas. Nessas situações, não há ofensa ao princípio da separação dos Poderes, porquanto a concretização dos direitos sociais não pode ficar condicionada à boa vontade do administrador, competindo ao Judiciário, nesses casos, operar como órgão controlador da atividade administrativa: 
Trata-se do movimento no sentido de ver o Direito e a Justiça não mais no quadro da concepção tradicional - a concepção 'oficial' dos que criam o direito, governam, julgam e administram -, mas sobretudo no quadro de concepção bem mais democrática, a dos consumidores do Direito e da Justiça. Em outros termos, a responsabilidade judicial deve ser vista não em função do prestígio e da independência da magistratura enquanto tal, nem em função do poder de uma entidade abstrata como o 'Estado' ou o 'soberano', seja este indivíduo ou coletividade. Ela deve ser vista, ao contrário, em função dos usuários, e, assim, como elemento do sistema de justiça que conjugue a imparcialidade - e aquele tanto de separação ou isolamento político e social que é exigido pela imparcialidade - com razoável grau de abertura e sensibilidade à sociedade e aos indivíduos que a compõem, a cujo serviço exclusivo deve agir o sistema judiciário (CAPPELLETTI, 1989, p. 99).

O princípio da separação dos Poderes não pode ser empregado como impedimento à consumação dos direitos sociais. Isso porque, ao se referir a direito fundamental, dentro do conceito de mínimo existencial, não haverá obstáculo jurídico para que o Judiciário estabeleça a inserção de determinada política pública nos planos orçamentários do ente político, principalmente quando não existir prova objetiva da incapacidade econômico-financeira do ente estatal.

A argumentação da teoria da reserva do possível, advinda do Direito alemão, não deve ser utilizada como escudo para o Estado brasileiro deixar de cumprir suas obrigações prioritárias. Assim, não é correto querer aplicar preceitos do Direito comparado sem observar a realidade do Estado brasileiro, pois é certo que na Alemanha a população já dispõe de um mínimo de prestações materiais capazes de assegurar existência digna.

No Brasil, a situação acontece de forma diferente, já que não foram asseguradas condições mínimas para uma vida digna aos indivíduos. Por conta disso, a dignidade humana consiste num dos desígnios basilares do Estado brasileiro, significando que somente 
após a captação do mínimo existencial é que se poderá controverter, no que toca aos recursos remanescentes, em quais ulteriores projetos se devem investir.

Ressalta-se que não se denega a ausência de recursos suficientes para acolher todas as atribuições que a Constituição e a Lei atribuíram ao Estado brasileiro. Entretanto, como não se pode impender tudo, carece-se afiançar aos indivíduos um mínimo de direitos primordiais para uma vida digna. Desse modo, inexistindo demonstração objetiva da incapacidade econômico-financeira do Estado, não haverá barreira jurídica para que o Judiciário motive a admissão de definida política pública nos planos orçamentários do ente estatal.

O Estado brasileiro, por meio da atividade judicante, passou a desempenhar maior grau de controle sob os demais poderes da república, bem como a prolatar juízos de valor que envolvem o exercício interpretativo de atos fundamentalmente políticos. Mesmo assim, a separação de Poderes, com a divisão tricotômica das funções, permanece como marco institucional, porém, com a consequente evolução de sua conceituação ao estágio social contemporâneo.

Diante disso, o acesso à justiça eficiente refere-se ao alcance da ordem jurídica justa, de modo que se possam solucionar as controvérsias de maneira satisfatória e palpável para o apaziguamento das relações sociais.

Portanto, o ativismojudicial consiste num método apto, devidamente respaldado na Constituição Federal, para que o cidadão tenha acesso à justiça eficiente, alcançando, dentro do cenário democrático do país, direitos fundamentais individuais e sociais para efetivação dos direitos humanos, do desenvolvimento e da paz social.

\section{Conclusão}

O instituto do acesso à justiça objetiva atender aos anseios comunitários de paz social, reforçando os mecanismos aptos a autorizar 
a elevação do cidadão à justiça qualitativa. A configuração do ativismo judicial em dizer o Direito confirma a nova cultura jurídica, que objetiva diminuir os problemas fáticos imediatos dos indivíduos em sociedade.

A escassez de direitos humanos básicos resulta na carência da autodeterminação social de parcela significativa da sociedade, que acarreta a simplória, formal e deplorável participação precária do povo no processo democrático. $\mathrm{O}$ acesso à justiça eficiente, por intermédio do ativismo judicial, deve ser tutelado pelo Estado enquanto praticado dentro da legislação, já que resulta na inclusão popular e na solidariedade social.

O fomento no acesso à justiça aproxima a justiça da população, direito humano básico estabelecido na Constituição da República Federativa do Brasil de 1988. A ascensão à justiça não trata apenas do ingresso do indivíduo à porta de entrada do Poder Judiciário, isenção de custas, advogados gratuitos (Defensoria Pública) ou até mesmo a dispensabilidade dos causídicos (Juizados Especiais), mas também diz respeito às garantias do contraditório, ampla defesa, razoável duração do processo, fundamentação das decisões, julgamento justo e, sobretudo, da eficácia das decisões proferidas.

O verdadeiro acesso à justiça, com a concretização dos direitos fundamentais, apenas será eficazmente efetivado quando o Estado aplicar um sistema ético de referência com o intuito da consecução dos bens mais importantes à humanidade. O contrário seria o Estado adotar um sistema arbitrário que representaria uma verdadeira lesão ao direito subjetivo constitucional, apto a ser corrigido pela via jurisdicional.

A competência para resolver conflitos dentro ou fora do processo judicial, a defesa individual ou coletiva e a promoção dos direitos humanos foram consagradas constitucionalmente como deveres do Estado para com o cidadão. Com isso, o acesso à justiça eficiente detém estabilidade normativa, mediante pertinente relevância política e finalística, ao passo que o ativismo judicial não denota invasão aos outros Poderes da República. 
Na hipótese de omissão do Poder Legislativo ou Executivo na consumação das políticas públicas dispostas a atender os direitos fundamentais, cabe ao Judiciário exercer controle de constitucionalidade e legalidade dos atos estatais a fim de corrigir omissões. A independência do Judiciário não o deixa restrito ou vinculado aos argumentos estatais, dotando-o do compromisso constitucional para a efetivação dos direitos fundamentais e obrigando seus membros a projetarem irradiação aos efeitos materiais da norma jurídica codificada.

O esgotamento do modelo clássico de separação dos Poderes encontra-se evidenciado com as problemáticas sociais vivenciadas. $O$ Estado constitucional permite o ativismo judicial dentro da legislação, em respeito ao regime democrático, ao colocar a sociedade e poder público com iguais direitos e deveres.

A imparcialidade do Judiciário, decorrente da sua independência constitucionalmente garantida, permite que não seja influenciado pelas vicissitudes político-partidárias, vinculando-se apenas aos objetivos do Estado Democrático de Direito. Com isso, o magistrado traz a lume toda a sua imparcialidade e independência ao efetivar determinadas políticas públicas em prol do jurisdicionado, uma vez que os Poderes constituídos existem para representar o povo e para ele devem funcionar.

A sólida musculatura da promoção da justiça qualitativa conduz ao arrefecimento da pobreza, gerando, assim, a emancipação social. Deveras, desenha-se um caminho importante para superar a crise democrática de agenciar a inclusão dos excluídos pela ação afirmativa do Estado, uma vez que traduz o direito do indivíduo em ter direitos.

O acesso à justiça eficiente apoia-se em ferramentas preciosas para a elevação dos direitos humanos, conjectura na qual o cidadão poderá fazer valer seus próprios direitos por meio da auferida consciência e a sua correspondente rogativa. $\mathrm{O}$ ativismo judicial referese à ultrapassagem das linhas demarcatórias da atividade jurisdicional, vindo ao encontro das necessidades populares para atingir a ordem jurídica justa, em que os magistrados devem, por meio da interpretação 
sistêmica e congruente, abonar concretude à Constituição garantindo justiça qualitativa e real.

O ativismo judicial garante aplicabilidade aos direitos e garantais constitucionais dos cidadãos, permitindo o equilíbrio necessário entre o direito positivo e a aplicabilidade da norma. Desse modo, o propositor das demandas judiciais e a sociedade possuem o direito de receber uma resposta do Estado-Juiz, motivo pelo qual o ativismo judicial permite demonstrar que o direito brasileiro pode evoluir desgarrado do positivismo, embora concomitante com a lei, somando-se as experiências, vivências e estudos para apreender o papel humanitário dos textos normativos.

Conclui-se que a atual etapa de acesso à justiça detém o propósito de consolidar o Estado Democrático de Direito, delineando o direito e o dever constitucional de avaliar a devida efetivação dos direitos basilares dos cidadãos. Nesse sentido, o Poder Judiciário deve corrigir as políticas públicas que não se coadunam com os fins constitucionais do Estado de Direito, assegurando a elevação de uma justiça qualitativa aos jurisdicionados.

\section{Referências}

\section{ANNONI, Daniele. Direitos Humanos $\&$ acesso à justiça no direito} internacional. Curitiba: Juruá, 2003.

ARISTÓTELES. A política. Trad. Roberto L. Ferreira. São Paulo: Nova Cultural, 1999.

BARROSO, Luís Roberto. Judicialização, ativismo Judicial e legitimidade democrática. Revista Eletrônica da Ordem dos Advogados do Brasil, Brasília, n. 3, 2008. Disponível em: <http:// www.plataformademocratica.org/Publicacoes/12685_Cached.pdf>. Acesso em: 18 ago. 2014.

BAUMAN, Zygmunt. Modernidade líquida. Trad. Plínio Dentzien. Rio de Janeiro: Zahar, 2001. 
BOBBIO, Norberto. A era dos direitos. Trad. Carlos Nelson Coutinho. Rio de Janeiro: Campus, 1992.

BRASIL. Constituição (1988). Constituição da República Federativa do Brasil, de 5 de outubro de 1988. Brasília: Senado Federal, 1988.

BUECHELE, Paulo Arminio Tavares. O princípio da proporcionalidade e a interpretação da Constituição. Rio de Janeiro: Renovar, 1999.

CAMPILONGO, Celso Fernandes. Política, sistema jurídico e decisão judicial. São Paulo: Max Limonad, 2002.

CAPPELLETTI, Mauro; GARTH, Bryant. Acesso à justiça. Trad. Ellen Gracie Northfleet. Porto Alegre: Fabris, 1988.

. Juízes irresponsáveis. Trad. Carlos Alberto Álvaro de Oliveira. Porto Alegre: Sérgio Antonio Fabris, 1989.

COMPARATO, Fábio Konder. A afirmação histórica dos direitos humanos. 3. ed. São Paulo: Saraiva, 2003.

DINAMARCO, Cândido Rangel. A instrumentalidade do processo. 7 . ed. São Paulo: Malheiros, 1999.

DWORKING, Ronald. O império do direito. Trad. Jefferson Luiz Camargo. São Paulo: Martins Fontes, 2005.

FERREIRA FILHO, Manuel Gonçalves. Princípios fundamentais do direito constitucional. São Paulo: Saraiva, 2009.

HÄBERLE, Peter. Estado constitucional cooperativo. Trad. Marcos Augusto Maliska e Elisete Antoniuk. São Paulo: 2007.

HOBBES, Thomas. Leviatã. Trad. João Paulo Monteiro e Mana Vizza. Petrópolis: Abril Cultural, 1979.

De cive: elementos filosóficos a respeito do cidadão. Trad. Ingeborg Soler. Petrópolis: Vozes, 1993. 
KELSEN, Hans. Jurisdição constitucional. Trad. Alexandre Krug, Eduardo Brandão e Maria Ermantina Galvão. São Paulo: Martins Fontes, 2003.

LOCKE, John. Segundo Tratado sobre o Governo. São Paulo: Abril, 1983.

LORENZETTI, Ricardo Luis. Teoria da decisão judicial: fundamentos de Direito. Trad. Claudia Lima Marques. São Paulo: Revista dos Tribunais, 2009.

MONTESQUIEU, Charles de Secondat, Baron de. O espírito das leis: as formas de governo, a federação, a divisão de poderes, presidencialismo versus parlamentarismo. 6. ed. Trad. Pedro Vieira Mota. São Paulo: Saraiva, 1999.

NOJIRI, Sergio. A interpretação judicial do Direito. São Paulo: Revista dos Tribunais, 2009.

PIOVESAN, Flávia. Direitos humanos e o direito constitucional internacional. 4. ed. São Paulo: Max Limonad, 2000.

RAMOS, Elival da Silva. Ativismo Judicial. São Paulo: Saraiva, 2010. REALE, Miguel. Filosofia do direito. 7. ed. São Paulo: Saraiva, 1975.

SANTOS, Boaventura de Sousa. Pela mão de Alice: o social e o político na pós-modernidade. São Paulo: Cortez, 1995.

SEN, Amartya. Well-Being, agency and freedom. The Journal of philosophy, New York, LXXXII, p. 169-221, 1985.

SILVEIRA, Vladmir Oliveira da; ROCASOLANO, Maria Mendez. Direitos humanos: conceitos, significados e funções. São Paulo: Saraiva, 2010.

Recebido em: 01/07/2015 Aprovado em: 14/07/2015 